\title{
Understanding the Internal Variability of Mudstones: Dark Mudstone of the Campano- Maastrichtian Mamu Formation as Case Study
}

\author{
"EDEGBAI, AJ; EMOFURIETA, WO
}

Department of Geology, Faculty of Physical Sciences, University of Benin, Benin-City, Nigeria
${ }^{*}$ Corresponding Author Email: aitalokhai.edegbai@uniben.edu; Tel: +2348137114844

\begin{abstract}
The objective of this research work was to investigate approximately $6 \mathrm{~m}$ of Campano-Maastrichtian dark mudstone outcropping at Uzebba, Benin Flank, SW Anambra Basin using sedimentological, geochemical, mineralogical, and palynofacies techniques. Our findings show that the mudstone succession can be subdivided into 3broad units from bottom to top. Unit 1 is characterized by weak to moderate bioturbation, high quartz content $(\geq 50 \%)$ as well as grained dominated microfabric with planar to wavy laminations. Unit 2 has the lowest particle size, zero to mild bioturbation, low quartz content as well as matrix dominated microfabric with thin to indistinct laminations, which are mostly planar. Unit 3 show intermediate particle size, weak to moderate bioturbation, moderate quartz content as well as grain dominated microfabric with much thicker laminations than units 1 and 2 that vary from wavy to curved. Geochemical and palynofacies proxies for detrital influx and paleoproductivity are congruent. They show that units 1 and 3 received significant detrital contribution as well as high terrestrial paleoproductivity under low relative sea level, which promoted the development of good petrophysical and geomechanical properties suitable for gas shale development. Conversely, Unit 2 received less significant detrital contribution as well as increased marine paleoproductivity under higher relative sea level.
\end{abstract}

DOI: https://dx.doi.org/10.4314/jasem.v24i5.18

Copyright: Copyright $(0) 2020$ Edegbai and Emofurieta. This is an open access article distributed under the Creative Commons Attribution License (CCL), which permits unrestricted use, distribution, and reproduction in any medium, provided the original work is properly cited.

Dates: Received: 31 February 2020; Revised: 27 April 2020; Accepted: 11 May 2020

Keywords: Detrital influx, paleoproductivity, unconventional reservoirs, Benin flank

Mudstones (also called shale or mudrock) are fine grained rocks, which comprise $50 \%$ or more of clay and silt-size particles (i.e., particles $<62.5 \mu \mathrm{m}$ ), and consist of clay minerals, quartz and calcite with interand intraformational variability. Consequently, no two mudstones are the same (Chelini et al. 2010). At a first glance, a mudstone succession may pass as being homogenous; but when examined with greater detail, its textural and compositional heterogeneity become obvious (Macquaker and Davies, 2008). This multiscale internal heterogeneity, which is controlled by syn- and post-depositional (diagenetic, maturation) processes that are similar to what is seen in sandstones and carbonates (Macquaker and Gawthorpe, 1993; Macquaker et al., 2007; Taylor, Per com., 2014; Lazar et al., 2015). This mean that the favourable petrophysical and geomechanical properties sought after in mudstone plays are not uniformly distributed. Principles of sequence stratigraphy explain how interactions between rate of sedimentation, eustacy, basin tectonics and climate determine grain-size, mineralogy, organic richness and rate of diagenesis in mudstone successions; thus, are primary defining lithofacies elements (Macquaker et. al., 2007; Bohacs and Schwalbach, 1992; Leithold 1994). Therefore, an understanding of the internal heterogeneity of mudstone requires a multidisciplinary approach, involving the integration of geochemical, sedimentological, palynological and mineralogical analyses. Petrographic studies (Schieber, 1994a, 1994b) come in handy in describing, understanding and predicting these macro and micro scale internal lithofacies variation of mudstone reservoirs. The dark mudstone lithofacies of the Campano-Maastrichtian Mamu Formation outcropping at the Benin Flank, SW Anambra Basin is laterally heterogeneous, and has been interpreted based on facies analysis to be the product of marsh, bay and central basin subenvironments in order of proximality to provenance. The aim of this study therefore, is to characterize the marsh mudstone succession outcropping at Uzebba, Edo State, using sedimentological, geochemical, mineralogical, and palynofacies techniques. This study is apt as it demonstrates how multidisciplinary tools can be used to understand the mudstone heterogeneity from outcrop to thin-section scale.

Geological framework: The Anambra Basin is the thermal sag phase of the Benue trough evolution which formed after the widespread inversion tectonics (Figure 1). This inversion, which brought about folding, faulting, volcanism, uplift and erosion of pre- 
Santonian sediments was diachronous, as the southern Benue trough (or Abakaliki Basin) was affected during the Santonian, whilst the northeastern Benue trough was affected during the Maastrichtian (Nwajide, 2013). As a result, portions of the pre-Santonian sedimentary fill of the Benue trough that were exhumed and eroded after the Santonian tectonics as well as basement rocks sourced its lithic fill (Benkhelil, 1982; Amajor, 1987; Odigi, 2007; Edegbai, et al., submitted). The Anambra Basin is about $55,000 \mathrm{~km}^{2}$ in area, and it is bordered to the West, East, and South by the Benin hinge line (also known as the Okitipupa structure), Southern Benue trough and Niger delta Basin respectively (Figure 1). Geographically, it can be separated to eastern and western sections by the River Niger. The basin has a Campanian to Danian fill that is thicker in the eastern section (Fig.1) and thins out on the basin fringes (Agagu and Adighije, 1983). Sedimentation began with the Nkporo Group with the largely marine in the east and alluvial to fluvial in the North and Western parts of the basin (Nwajide, 2013). This was succeeded by the deposition of the estuarine, lagoonal and tidal flat facies of the Mamu Formation (Ladipo, 1988; Edegbai et al., 2019), the subtidal/shallow marine Ajali Formation (Nwajide, 2013), and the Nsukka Formation which has similar lithofacies as the Mamu Formation (Nwajide, 2013) in stratigraphic order.
Lithostratigraphy of the Mamu Formation in the Benin Flank: Outcrop studies have shown that 7- lithofacies characterize the Mamu Formation in the Benin Flank. These lithofacies comprise of: the dark mudstone unit, the thin bedded sandy mudstone - sandstone unit, the light coloured weakly to mildly bioturbated sheet-like sandy mudstone-muddy sandstone unit, the oolitic ironstone unit, the cross-bedded sand unit, the light coloured medium mudstone to muddy sandstone unit, and the heterolithics unit. Based on facies analysis, these units depict marsh, bay, barrier, beach, and washover fan facies association as well as meandering fluvial-tidal channel facies association that typifies a tidally influenced wave dominated estuarine paleoenvironment (Edegbai et al., 2019).

\section{MATERIALS AND METHODS}

This study was undertaken in Uzebba (N $06^{0} 58^{\mathrm{I}} 04.3^{\mathrm{II}}$, E $05^{0} 51^{\mathrm{I}} 23.2^{\mathrm{II}}$ ) Benin Flank, SW Anambra Basin. The Uzebba outcrop (Fig. 1) represents the marsh facies (Edegbai et al. 2019), and approximates the basal to mid-section of the Mamu Formation. Detailed outcrop description was carried out, following which 24 samples were selected for particle size and total organic carbon analyses, whereas 21 samples were selected for mineralogical and geochemical analyses. Petrographic thin-sections for microfabric analysis was prepared for a few samples.

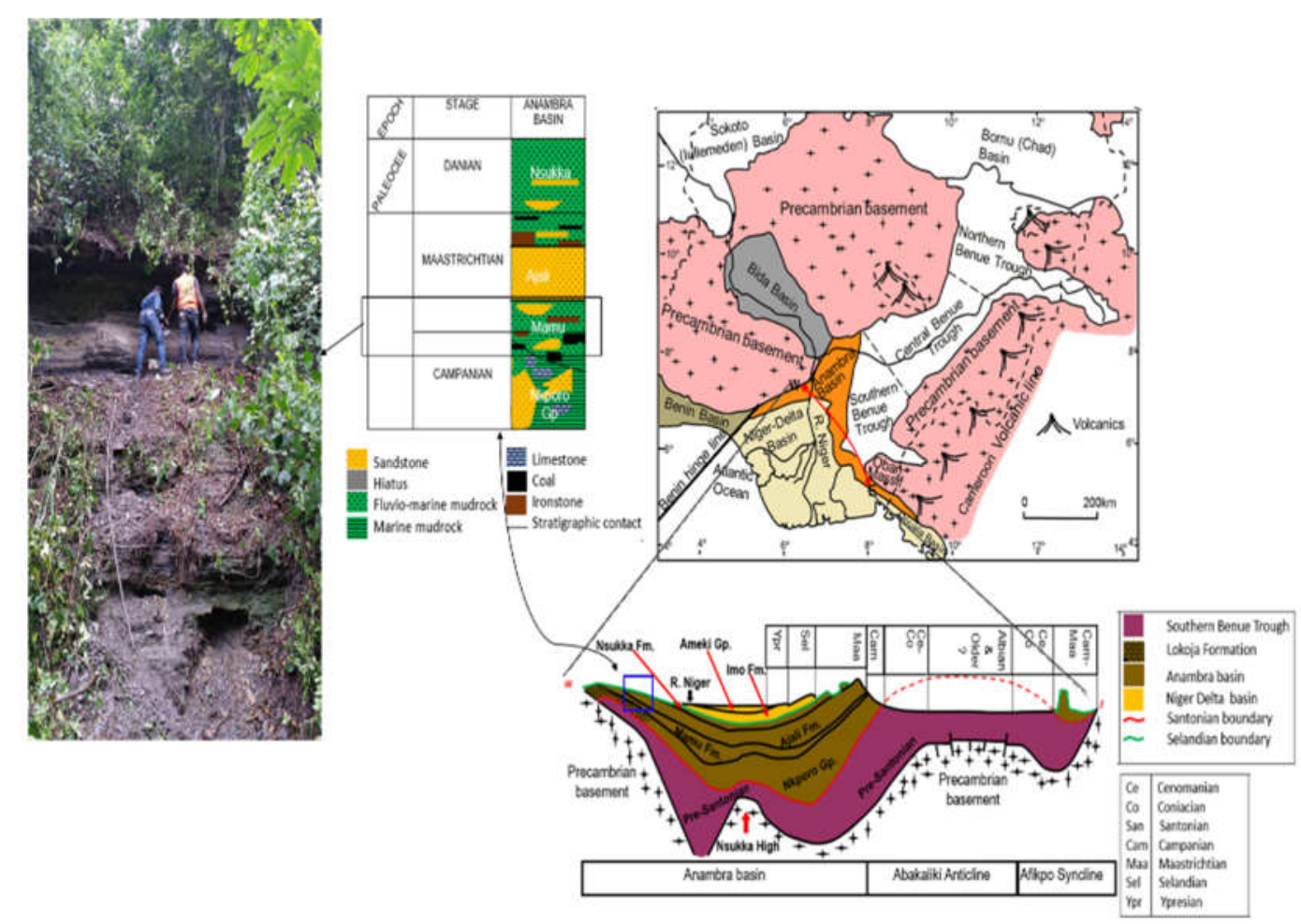

Fig 1: Regional Geology and tectonic framework of the Anambra Basin (adapted from Edegbai et al., 2019). In set picture is the marsh mudstone succession outcropping at Uzebba 
The Particle size analysis was carried out using a Microtrac S3500 laser diffraction analyzer at Missouri University of Science and Technology, Rolla MO, USA. Cumulative frequency curves were subsequently plotted from the raw data from which the percentages of clay, silt and sand fractions were determined. Mineralogical analysis was carried out on 21 samples using acid test as well as a by a PANalytical X'Pert Pro multi-purpose X-ray Diffractometer (XRD). Whole rock elemental analysis was carried out on 21 samples using PANalytical Axios Max XRF at acme lab, Canada. All oxides were converted to element percent or ppm. Subsequently, characterization of the dark mudstone lithofacies was done after integrating data from outcrop studies, particle size, mineralogical, geochemical and palynofacies analyses.

\section{RESULTS AND DISCUSSION}

A summary of the results of the geochemical, mineralogical, sedimentological and palynofacies assessment is presented in Tables 1a-b. Palynofacies data reveal that the phytoclast group is the principal organic matter constituent in all the samples analyzed amounting to up to $92 \%$ in some instances.

The mean percentage phytoclast amounts to $88.27 \%$ $(\mathrm{S} . \mathrm{D}=3.03)$, followed by the sporomorph group with an average of $8.96 \%(S . D=2.93)$. The microplankton group is the least abundant with a mean of $0.55 \%$ (table 1a). The average TOC of the samples is $1.13 \mathrm{wt}$. $\%(\mathrm{~S} . \mathrm{D}=0.21)$. A large proportion of the samples have TOC $>1$ wt. $\%$, while $16.67 \%$ of the samples have TOC below 1 wt. \% (table 1a).

In addition, the mineral assemblage is dominated by quartz and kaolinite, while calcite is lacking. Binary plot of quartz and total clay following an amendment of Lazar et al (2015)'s template show that the samples vary from argillaceous - siliceous (AR-SI) to siliceous - argillaceous (SI-AR), with a large proportion being SI-AR.

This is consistent with data from whole rock elemental analysis results, which show that $\mathrm{Si}$ and $\mathrm{Al}$ are the most concentrated elements in the samples analyzed (table $1 \mathrm{~b}$ ). Mean values of $\mathrm{Si}, \mathrm{Al}, \mathrm{Ti}, \mathrm{K}, \mathrm{P}, \mathrm{Sr}$, and $\mathrm{Zr}$ are $31.7 \%$ (S.D $=3.82), 8.88 \%(\mathrm{~S} . \mathrm{D}=2.03), 0.95 \%$ $(\mathrm{S} . \mathrm{D}=0.1), 0.28 \%(\mathrm{~S} . \mathrm{D}=0.06), 0.04 \%(\mathrm{~S} . \mathrm{D}=$ 0.009), $220 \mathrm{ppm}(\mathrm{S} . \mathrm{D}=51.4)$ and $156.7 \mathrm{ppm}(\mathrm{S} . \mathrm{D}=$ 23.15) respectively.

Ternary plot of the relative abundance of clay $\%$, silt $\%$ and sand \% (Lazar et al., 2015), show the dark mudstone plotting mostly in the mudstone field (Fig 2). $45.8 \%$ of the samples are medium mudstones, while $25 \%, 20.8 \%$ are coarse mudstones and sandy mudstones respectively.

Microfabric analysis and detrital influx: Integrating data from geochemistry, palynofacies, mineralogy and microfabric observations, the marsh mudstone can be subdivided into 3 units representing realms of proximality in the marsh sub-environment was identified and characterized.

Unit 1: Characterized by $\mathrm{mMs}$ to $\mathrm{mSs}$, weakly to moderately bioturbated with quartz content, plotting in the SI-AR (50-75\% quartz) field (Fig. 2).

Geochemical indices of detrital influx: Si/Al, Ti/Al, $\mathrm{Zr} / \mathrm{Al}$ (Calvert and Pedersen, 2007) complemented by quartz/ total clay are congruent (Fig. 3). They all indicate that this unit on the average possess the largest grain size and has received significant detrital contribution from provenance regions in comparison to the other units. Microfabric analysis reveal grain dominated fabric with planar to wavy laminations (Fig. 4).

Unit 2: Characterized by $\mathrm{fMs}$ to $\mathrm{mMs}$, low quartz content, plotting in the AR-SI (25-49 \% quartz) field (Fig. 2). Microfabric analysis reveal thin to indistinct laminations, which are mostly planar, matrix dominated with zero to mild bioturbation (Fig. 4), This unit has the lowest grain size and is the least clastic diluted unit as revealed by geochemical proxies as well as quartz/ total clay (Fig. 3).

Unit 3: Characterized by $\mathrm{mMs}$ to $\mathrm{mSs}$, moderate quartz content, plotting in AR-SI and SI-AR fields (Fig. 2-3). This unit show much thicker lamination (in comparison with the other units), with wavy to curved fabric as well as weak to moderate bioturbation (Fig. 4). Detrital influx proxies show moderate to significant clastic dilution (Fig. 3).

Relative sea-level fluctuations and paleoproductivity: From the microfabric analysis above, we can broadly deduct one full cycle of relative sea level. Unit 1 show progradation typified by large grainsize, significant detrital influx and high quartz content (Fig. 3).

Palynofacies data show prevalence of phytoclast, little sporomorph, AOM, fungi and very little microplankton (Table 1a) implying very high terrestrial paleoproductivity. This unit is proximal, shallow with high rate of sedimentation. Unit 2 depict retrogradation to aggradation typified by lower grainsize, thin lamination, less significant detrital influx as well as low quartz content (Fig. 3-5). 

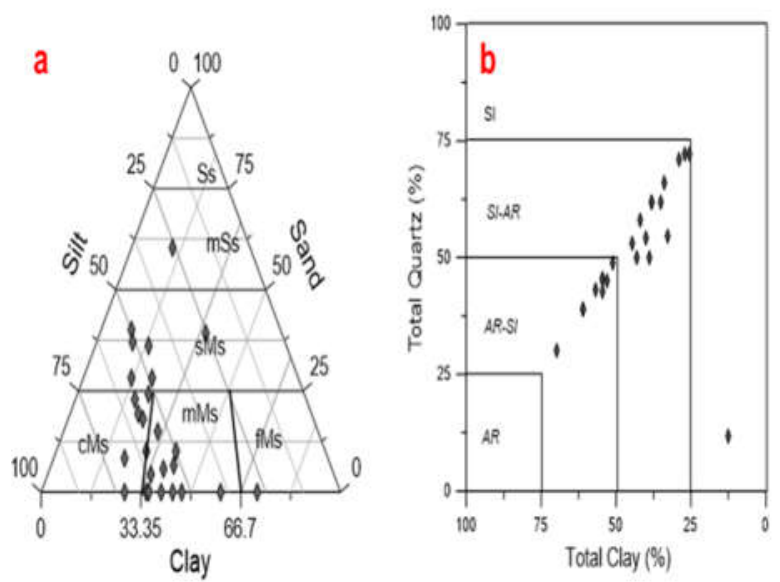

Fig. 2. a, Ternary plot for particle size analysis of mudstone (adapted from Lazar et al., 2015); b, binary plot of quartz $v s$. total clay used for mineralogical characterization adapted from Lazar et al., 2015).

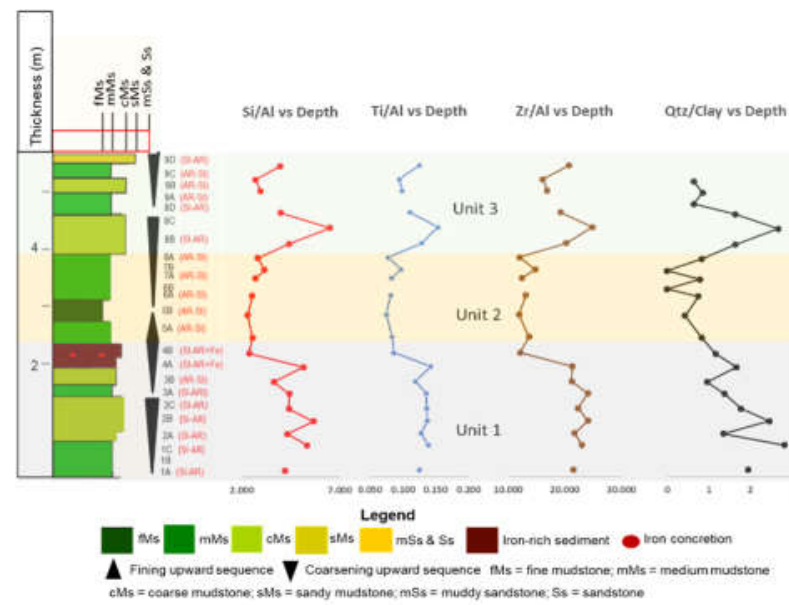

Fig. 3: graphic log of Uzebba out crop with sample points, mineralogical character as well as geochemical proxies for detrital

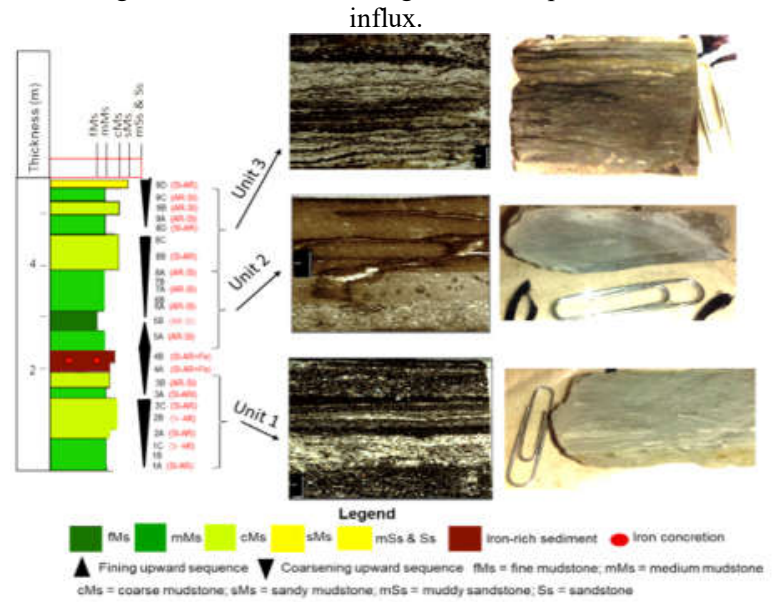

Fig. 4. Graphic log of Uzebba outcrop with sample points, mineralogical character as well brickets and thin-sections representative of the identified subdivisions.

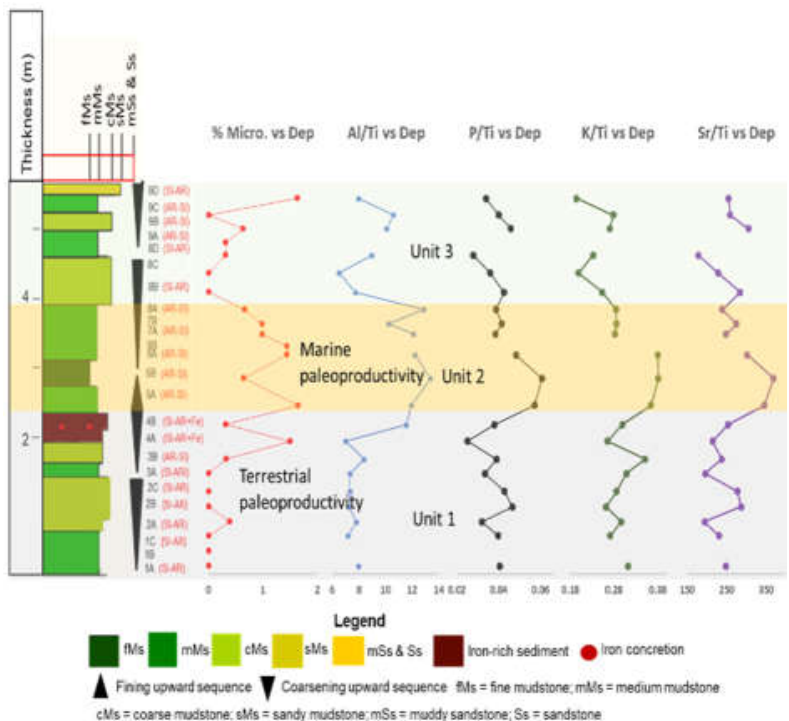

Fig. 5: Graphic log of Uzebba out crop with sample points, mineralogical character as well as geochemical and palynofacies proxies for paleoproductivity

The presence of microplankton is indicative of flooding and some degree of marine paleoproductivity (Fig. 5). Marine productivity is confirmed by geochemical proxies of productivity ( $\mathrm{Al} / \mathrm{Ti}$, $\mathrm{P} / \mathrm{Ti}$,(Calvert and Pedersen, 2007) and $\mathrm{Sr} / \mathrm{Ti})$, as well as illitization of kaolinitic clay (K/Ti) (Fig. 5). This unit is more distal from provenance, deeper with lower rate of sedimentation. Unit 3 show progradation typified by intermediate grainsize, high detrital influx and moderate quartz content (Fig. 3-4).

Palynofacies data complemented by geochemical data indicate much lower marine paleoproductivity and higher terrestrial paleoproductivity in comparison with unit 2 (Fig. 5). This unit is proximal, shallower than unit 1 with the highest rate of sedimentation. It is important to mention that across the units, total organic carbon (TOC) is fairly uniform (table 1a). This is attributed to the high terrestrial paleoproductivity and consequent phytoclast dilution in the marsh subenvironment. This hypothesis is supported by good positive correlation of redox sensitive trace metals and aluminum (Edegbai et al., 2019).

Implication for unconventional gas development: Insight from microfabric assessment indicate the existence of good petrophysical and geomechanical properties, which are desirable for gas shale development (Burns et al., 2012; Bouhlel et al., 2012). 
Understanding the Internal Variability of Mudstones.....

Table 1a: Results of palynofacies, particle size and XRD analyses

\begin{tabular}{|c|c|c|c|c|c|c|c|c|c|c|c|c|c|c|}
\hline \multirow[t]{2}{*}{$\mathrm{S} / \mathrm{N}$} & \multirow[t]{2}{*}{ Depth } & \multicolumn{6}{|c|}{ Palynofacies Data } & \multirow{2}{*}{ TOC } & \multicolumn{3}{|c|}{ Particle size analysis Data } & \multicolumn{3}{|c|}{ XRD Data } \\
\hline & & Phytoclast & $\mathrm{AOM}$ & Fungal spore and hyphae & Pollen & Spore & Marine algae & & Sand & silt & Clay & Total clay & Quartz & Quartz/Clay \\
\hline U1 IA & 0.12 & 372 & 8 & 8 & 4 & 11 & 0 & 1.35 & 8 & 68 & 24 & 34 & 66 & 1.94 \\
\hline U1 1B & 0.34 & 230 & 3 & 2 & 0 & 13 & 0 & 1.33 & 22.5 & 57.5 & 20 & - & - & - \\
\hline $\mathrm{U} 1 \mathrm{1C}$ & 0.56 & 270 & 4 & 3 & 2 & 17 & 0 & 1.19 & 4 & 61.5 & 34.5 & 25.7 & 72.3 & 2.81 \\
\hline U1 2A & 0.76 & 215 & 3 & 0 & 8 & 30 & 1 & 1.22 & 24 & 52 & 24 & 40 & 54 & 1.35 \\
\hline U1 2C & 1.2 & 245 & 3 & 8 & 9 & 32 & 0 & 1.16 & 40 & 50 & 10 & 35 & 62 & 1.77 \\
\hline U1 3A & 1.46 & 273 & 2 & 6 & 6 & 20 & 0 & 1.24 & 0 & 40 & 60 & 42 & 58 & 1.38 \\
\hline $\mathrm{U} 13 \mathrm{~B}$ & 1.67 & 269 & 2 & 8 & 1 & 24 & 1 & 1.2 & 0 & 72 & 28 & 51 & 49 & 0.96 \\
\hline U1 4a & 1.93 & 300 & 3 & 4 & 7 & 13 & 5 & 1.04 & 0 & 53 & 47 & 32.7 & 54.5 & 1.67 \\
\hline $\mathrm{U} 14 \mathrm{~b}$ & 2.17 & 266 & 4 & 9 & 4 & 29 & 1 & 1.13 & 0 & 56 & 44 & 43 & 50 & 1.16 \\
\hline U1 5A & 2.45 & 269 & 4 & 0 & 3 & 23 & 5 & 1.78 & 18 & 57 & 25 & 54.5 & 45.5 & 0.83 \\
\hline U1 5B & 2.84 & 279 & 2 & 1 & 4 & 21 & 2 & 1.21 & 0 & 28 & 72 & 70 & 30 & 0.43 \\
\hline $\mathrm{U} 16 \mathrm{~A}$ & 3.18 & 347 & 2 & 7 & 6 & 47 & 6 & 1.09 & 10 & 60 & 30 & 57 & 43 & 0.75 \\
\hline U1 6B & 3.31 & 347 & 2 & 7 & 6 & 47 & 6 & 1.17 & 19 & 58 & 23 & - & - & - \\
\hline U17A & 3.48 & 267 & 8 & 2 & 6 & 18 & 3 & 1.12 & 0 & 60 & 40 & 54.4 & 42.6 & 0.78 \\
\hline U1 7B & 3.63 & 267 & 8 & 2 & 6 & 18 & 3 & 1.03 & 0 & 65 & 35 & - & - & - \\
\hline $\mathrm{U} 18 \mathrm{~A}$ & 3.84 & 278 & 6 & 0 & 0 & 16 & 2 & 1.16 & 6.5 & 52.5 & 41 & 54.5 & 45.5 & 0.83 \\
\hline U1 $8 \mathrm{~B}$ & 4.09 & 280 & 2 & 1 & 4 & 22 & 0 & 1.2 & 37 & 51 & 12 & 38 & 62 & 1.63 \\
\hline U1 8C & 4.37 & 280 & 2 & 1 & 4 & 22 & 0 & 0.97 & 28 & 49 & 23 & 27 & 72 & 2.67 \\
\hline U1 8D & 4.63 & 285 & 4 & 10 & 3 & 14 & 1 & 1.07 & 10 & 50 & 40 & 38 & 62 & 1.63 \\
\hline U19A & 4.81 & 285 & 4 & 10 & 3 & 14 & 1 & 1.2 & 5.5 & 56.5 & 38 & 61 & 39 & 0.64 \\
\hline U1 9B & 5.01 & 271 & 5 & 2 & 2 & 31 & 2 & 1.09 & 36 & 46 & 18 & 53 & 45 & 0.85 \\
\hline U1 9C & 5.21 & 277 & 6 & 1 & 7 & 16 & 0 & 0.8 & 0 & 64 & 36 & 61 & 39 & 0.64 \\
\hline
\end{tabular}

Table 1b: Results of geochemical analysis

\begin{tabular}{|c|c|c|c|c|c|c|c|c|c|c|c|c|c|c|c|}
\hline $\mathrm{S} / \mathrm{N}$ & Depth & \multicolumn{14}{|c|}{ Geochemical analysis data } \\
\hline U1 IA & 0.12 & 33.89 & 8.04 & 1.01 & 0.32 & 0.04 & 225 & 173.2 & 4.21 & 0.13 & 21.53 & 7.99 & 0.04 & 0.313 & 248.34 \\
\hline U1 1B & 0.34 & - & - & - & - & - & - & - & - & - & . & - & - & - & - \\
\hline U1 $1 \mathrm{C}$ & 0.56 & 36.27 & 6.83 & 0.95 & 0.26 & 0.04 & 192 & 157 & 5.31 & 0.14 & 23.00 & 7.21 & 0.04 & 0.272 & 230.77 \\
\hline U1 $2 \mathrm{C}$ & 1.2 & 34.73 & 7.89 & 1.07 & 0.31 & 0.05 & 261 & 176.6 & 4.40 & 0.14 & 22.39 & 7.35 & 0.05 & 0.286 & 278.25 \\
\hline U1 3A & 1.46 & 34.22 & 7.73 & 1.05 & 0.32 & 0.04 & 182 & 186.1 & 4.43 & 0.14 & 24.08 & 7.37 & 0.04 & 0.309 & 195.70 \\
\hline U1 3B & 1.67 & 33.05 & 9.10 & 1.09 & 0.38 & 0.05 & 225 & 193.3 & 3.63 & 0.12 & 21.23 & 8.39 & 0.04 & 0.352 & 238.10 \\
\hline U1 4a & 1.93 & 27.01 & 5.26 & 0.75 & 0.20 & 0.02 & 130 & 112.4 & 5.13 & 0.14 & 21.37 & 7.02 & 0.03 & 0.266 & 214.88 \\
\hline U1 5B & 2.84 & 28.84 & 12.54 & 0.94 & 0.36 & 0.06 & 315 & 149.9 & 2.30 & 0.07 & 11.95 & 13.41 & 0.06 & 0.382 & 369.28 \\
\hline U1 6A & 3.18 & 29.73 & 11.75 & 0.96 & 0.37 & 0.05 & 263 & 155 & 2.53 & 0.08 & 13.19 & 12.25 & 0.05 & 0.381 & 302.65 \\
\hline U1 6B & 3.31 & - & - & - & - & - & - & - & - & - & 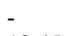 & - & - & - & - \\
\hline U1 7A & 3.48 & 28.89 & 10.69 & 0.88 & 0.25 & 0.04 & 190 & 133.1 & 2.70 & 0.08 & 12.45 & 12.13 & 0.04 & 0.283 & 248.69 \\
\hline U1 7B & 3.63 & 31.10 & 9.84 & 0.96 & 0.27 & 0.04 & 239 & 146 & 3.16 & 0.10 & 14.83 & 10.26 & 0.05 & 0.286 & 275.98 \\
\hline U1 8A & 3.84 & 29.57 & 10.50 & 0.82 & 0.23 & 0.03 & 186 & 126.5 & 2.82 & 0.08 & 12.05 & 12.88 & 0.04 & 0.285 & 239.69 \\
\hline U1 8B & 4.09 & 33.61 & 7.62 & 0.98 & 0.25 & 0.05 & 248 & 154.9 & 4.41 & 0.13 & 20.32 & 7.75 & 0.05 & 0.253 & 285.06 \\
\hline U1 8C & 4.37 & 37.11 & 5.72 & 0.88 & 0.17 & 0.03 & 184 & 142.2 & 6.49 & 0.15 & 24.88 & 6.53 & 0.04 & 0.199 & 228.86 \\
\hline
\end{tabular}


High quartz content in units 1 and 3 (Fig. 2- 4) equate to an increase in brittleness index, which favour the development of natural and secondary (induced) fractures (Ding et al., 2012). In addition, it is envisaged that the grain dominated microfabric, higher degree of bioturbation and interbeds of cMs and sMs (Fig. 2-5), as well as the tendency for fracture propagation observed in units 1 and 3 will promote an increase in porosity and permeability (Ding et al., 2012) in comparison with unit 2.

Conclusion: This study has shown that the marsh mudstone succession at Uzebba can be subdivided into 3-broad units. Low relative sea level promoted the deposition of proximal units (units 1 and 3) with coarser grainsize, high quartz content, mild to moderate degree of bioturbation, grain dominated fabric with evidence of significant clastic contribution. Whereas higher relative sea level promoted the deposition of unit 3 in deeper water characterized by finer grain size, low quartz content as well as low degree of bioturbation and matrix dominated fabric.

Acknowledgement: Edegbai is grateful to the University of Benin Research and Publications Committee, the Fulbright Commission (15160892), the Niger Delta Development Commission (NDDC/DEHSS/2015PGFS/EDS/011), and the DAAD (ST32 - PKZ: 91559388) for contributing to his educational development over the years. Julius Imarhiagbe provided great field assistance. In addition, the immense contributions provided by Professors' L.S Schwark and F.E. Oboh-Ikuenobe in this project are also worthy of mention.

\section{REFERENCES}

Agagu, OK; Adhijie, CI (1983). Tectonic and sedimentation framework of the Lower Benue Trough, Southeastern: Nigeria, J. Afr. Earth Sci. 1 (3-4): 267-274

Amajor, LC (1987). Paleocurrent, Petrography and Provenance analyses of the Ajali Sandstone (upper Cretaceous), southeastern Benue trough, Nigeria. Sediment. Geol. 54: 47-60

Benkhelil, J (1982). Benue Trough and Benue Chain. Geol. Mag. 119: 155-168.

Bohacs, K; Schwalbach, JR (1992). Sequence stratigraphy in fine grained rocks: examples from the Monterey Formation. SEPM Field Guide 70: $1-80$
Bouhlel, AM; Bryant, I (2012). An effective Approach to Unconventional Resource Exploration in the Middle East. SPE Middle East Unconventional Gas Conference and Exhibition, Abu Dhabi, $U A E$ : Paper 152455

Burns, C; Topham, A; Lakani, R (2012). The Challenges of Shale Gas Exploration and Appraisal in Europe and North Africa. SPE/EAGE European Unconventional Resources Conference and Exhibition, Vienna, Austria: Paper 151868

Calvert, SE; Pedersen, TF (2007). Elemental proxies for palaeoclimatic and Palaeoceanographic variability in marine sediments: interpretation and application. In: Hillaire-Marcel, C; de Vernal, A (ed) Paleoceanography of the Late Cenozoic. Part 1 Methods in Late Cenozoic Paleoceanography. Elsevier, New York, p. 567-644.

Chelini, V; Muttoni, A; Maurizio, M; Rossi, E; Galimberti, R; Ortenzi, A (2010). Gas Shale Reservoir characterization: A North Africa Case. SPE Annual Technical Conference and Exhibition, Florence, Italy: Paper 134292

Ding, W; Li, C; Xu, C; Jiu, K; Zeng, W; Wu, L (2012). Fracture development in shale and its relationship to gas accumulation. Geos. Frontiers 3(1): 97-105

Edegbai, AJ; Schwark, L; Oboh-Ikuenobe, FE (2019). Campano-Maastrichtian paleoenvironment, paleotectonics and sediment provenance of western Anambra Basin, Nigeria: multi-proxy evidences from the Mamu Formation. J. Afr. Earth Sci. 156: 203-239

Ladipo, KO (1988). Paleogeography, sedimentation and tectonics of the upper Cretaceous Anambra Basin, South-eastern Nigeria. J. Afr. Earth Sci. 7: 865- 871

Lazar, OR; Bohacs, KM; Macquaker, JHS; Schieber, J; Demko, TM (2015). Capturing key attributes of fine-grained sedimentary rocks in outcrops, cores and thin sections: nomenclature and description guidelines: J. Sediment. Res. 85: 230-246.

Leithold, EL (1994). Stratigraphical architecture at the muddy margin of the Cretaceous Western Interior seaway, southern Utah: Sedimentology 41: 521542

Macquaker, JHS; Gawthorpe, RL (1993). Mudstone lithofacies in the Kimmeridge Clay Formation, Wessex Basin, Southern England: implications 
for the origin and controls of the distribution of mudstones: J. Sediment. Petrol. 63: 1129-1143.

Macquaker, JHS; Taylor, KG; Gawthorpe, RL (2007). Spatial Expression of Architectural Elements and Packages in a Large-Scale Outcropping Siliciclastic Mudstone Succession: The Mancos Shale, Book Cliffs, Utah. J Sediment. Res. 77: 324-339.

Nwajide, CS (2013). Geology of Nigeria's Sedimentary Basins. CSS Bookshop Ltd., Lagos, $565 \mathrm{p}$.

Odigi, MI (2007). Facies architecture and sequence stratigraphy of Cretaceous formations, southeastern Benue Trough, Nigeria. Unpublished Ph.D thesis, University of Port Harcourt, Nigeria, 288p.
Schieber, J (1994a). Evidence for episodic high energy events and shallow water deposition in the Chattanooga Shale, Devonian, central Tennessee, U.S.A. Sedimentary Geology 93: 193- 208

Schieber, J (1994b). Reflection of deep vs shallow water deposition by small scale sedimentary features and microfabrics of the Chattanooga Shale in Tennessee, In: Embry, AF; Beauchamp, B; Glass, DJ (eds) Pangea: Global Environments and Resources: Can. Soc. Petrol.Geologists, Memoir 17: 773 - 784

Total (1984). Some geochemical data in the Anambra Basin. Unpublished report, 05NG006-0142 